\title{
Metal distributions in seawater, sediment and marine benthic macroalgae from the South Australian coastline
}

\author{
S. Chakraborty • G. Owens
}

Received: 6 November 2012/Revised: 12 February 2013/Accepted: 23 April 2013/Published online: 17 May 2013

(C) Islamic Azad University (IAU) 2013

\begin{abstract}
Algal species which are ubiquitous along the coastlines of many countries reflect the environmental conditions of the coastal seawater and may serve as useful biomonitors of anthropogenic pollution. Heavy metal concentrations of ten elements (As, Cd, Co, Cr, Cu, Fe, $\mathrm{Mn}, \mathrm{Ni}, \mathrm{Pb}$ and $\mathrm{Zn}$ ) of potential environmental concern were determined in seawater, sediments and twelve species of benthic marine macroalgae from four locations (Glenelg, Port Adelaide, Port Broughton and Port Pirie) along the South Australian coastline. The four sites chosen represented varying degrees of metal contamination, where the capacity for benthic macroalgae to accumulate heavy metals from the environment was evaluated. Spatial differences in heavy metal concentration in both seawaters and sediments were observed at all sites with the highest concentrations of heavy metals including Cd $\left(125 \mu \mathrm{g} \mathrm{g}^{-1}\right)$, $\mathrm{Pb}\left(2,425 \mu \mathrm{g} \mathrm{g}^{-1}\right)$ and $\mathrm{Zn}\left(7,974 \mu \mathrm{g} \mathrm{g}^{-1}\right)$ found in the finer sediment fractions $(<250 \mu \mathrm{m})$ of Port Pirie. While all algal species studied (Acrosorium polyneurum, Anotrichium tenue, Cystophora Cephalornithos Cystophora monillifera,
\end{abstract}

Electronic supplementary material The online version of this article (doi:10.1007/s13762-013-0310-4) contains supplementary material, which is available to authorized users.

S. Chakraborty · G. Owens $(\square)$

Centre for Environmental Risk Assessment and Remediation,

University of South Australia, Mawson Lakes,

SA 5095, Australia

e-mail: Gary.owens@unisa.edu.au

S. Chakraborty

Environmental Science and Engineering Group, Birla

Institute of Technology, Mesra, Ranchi, India

G. Owens

Mawson Institute, University of South Australia, Mawson Lakes, SA 5095, Australia
Cystophora monilliformis, Dictyopteris australis, Gelidium micropterum, Gracilaria, Hormophysa Cuneiformis, Sargassum cinctum, Scaberia agardhii and Ulva lactuca) accumulated metals to varying degrees, Blindigia marginata was a good biomonitor species for a number of metals including $\mathrm{Cd}, \mathrm{Co}, \mathrm{Cr}, \mathrm{Fe}, \mathrm{Pb}$ and $\mathrm{Zn}$, exhibiting both relatively high total metal concentrations and significant concentration factors.

Keywords Bioaccumulation - Biomonitoring - Blindigia marginate - Contamination - Heavy metals - Seaweed . Sediment particle size

\section{Introduction}

Metal contamination of the coastal marine regions of the world is common (Millward and Turner 2001) and is of ecotoxicological importance because of the toxicity and long-term persistence of heavy metals (Claisse and Alzieu 1993). Although some natural discharges of metals occur, pollution and the consequential environment and ecological degradation are predominantly anthropogenic. While contaminated site assessment typically involves the analysis of water and sediment to measure total contaminant concentrations, often this analysis is not a good predictor of contaminant toxicity to biota (Gosavi et al. 2004). Consequently, aquatic organisms have become increasingly used in the assessment of contamination, as both 'biomonitors' and 'bioindicators' (Rainbow 2006; Villares et al. 2002). In particular, macroalgae have been commonly used as powerful biomonitors of metal pollution in seawater (Chaudhuri et al. 2007; Misheer et al. 2006). Previous Australian studies of metal contamination in the marine environmental have indicated that surficial sediments 
adjacent to most urbanized and industrialized estuaries are contaminated with metals, particularly $\mathrm{Pb}$ and $\mathrm{Zn}$ (Batley 1995). Consequently, a number of metal biomonitoring studies have been conducted in Australia employing a large number of different biological organisms to monitor a variety of different metals. Tropical oysters were used to monitor Cd levels in North Queensland coastal waters by Olivier et al. (2002) who observed that $\mathrm{Cd}$ accumulation in oysters increased as ambient dissolved $\mathrm{Cd}$ concentrations decreased. They concluded that for these oysters, the predominant source of $\mathrm{Cd}$ was from the particulate rather than the dissolved phase. Metal contamination levels and the effect on fishes in Port Kembla harbour, NSW were reviewed by $\mathrm{He}$ and Morrison (2001). He concluded that although the environment of the harbour had improved over the last 20 years, due to public pressure and increasingly stringent legislation requirements, there was still considerable scope to reduce the pollution load to sediment and marine organisms. In Victoria, the Asia-Pacific Mussel Watch program used sentinel organisms, such as mussels and oysters, as biomonitors for coastal water quality (Tanabe 1994). This study concluded that sewage wastes, which were commonly disposed to marine or estuarine waters with varying levels of treatment, resulted in a high degree of heavy metal pollution. However, this study is often criticized for insufficient temporal and spatial monitoring, absence of certain chemicals from the database and lack of consistency in sites. Some studies of macroalgae have shown distributional differences among estuaries with differing pollution loads, and correlations between sediment and algal metal concentrations (Melville and Pulkownik 2006). A significant decline of large macroalgae due to metal pollution in near shore habitats including South Australia, especially near sewerage discharge and urban run-off sites, has also been reported (Bellgrove et al. 1997). However, brown algae have been proposed as a suitable tool for biomonitoring the environmental impacts at effluent discharge sites in South Australia because they exhibit a high degree of reproducibility with low to modest temporal variation and apparent consistency in outcomes from disparate locations (Burridge and Bidwell 2002).

In South Australia, the Adelaide metropolitan coastline has been significantly degraded over the last 70 years due to a variety of land-based inputs including wastewater, stormwater and industrial effluents (Wilkinson et al. 2005a, b) which has resulted in the deterioration of critical aquatic habitats such as seagrass and reef ecosystems (Connell et al. 2008). However, pollution is not uniformly distributed along the coastline, but is concentrated in two industrial hotspots: Port Pirie (one of our sampling sites), in the upper Spencer Gulf, and Adelaide, in the Gulf of Saint Vincent (Edwards et al. 2001). Such anthropogenic hotspots of metal contamination have been previously documented (Zann 1995). It is logical that these contaminant hotspots correspond to areas of the coastline where human populations aggregate and industrial activities increase the effluence of contaminants into the environment. In this study, we report the degree of heavy metal contamination in water, sediment and algal species collected from four such areas along the South Australian coastline.

\section{Materials and methods}

Study sites

Four sampling locations (Glenelg, Port Adelaide, Port Broughton and Port Pirie) representing various levels of suspected metal contamination were chosen (Fig. 1). The choice of sampling locations was informed by earlier reports (Edwards et al. 2001; Ferguson 1983; Richardson et al. 1994) which had indicated that these sites may have potential for anthropogenic metal contamination due to a combination of urbanization and industrialization. Sampling occurred during autumn 2010 in the months of March, April and May. Among the four sampling sites, Port Pirie was believed to be the most polluted site compared to Port Broughton and Glenelg. Port Adelaide was considered to be moderately polluted due to industrial discharge and recreational cruise activities. At all sites,

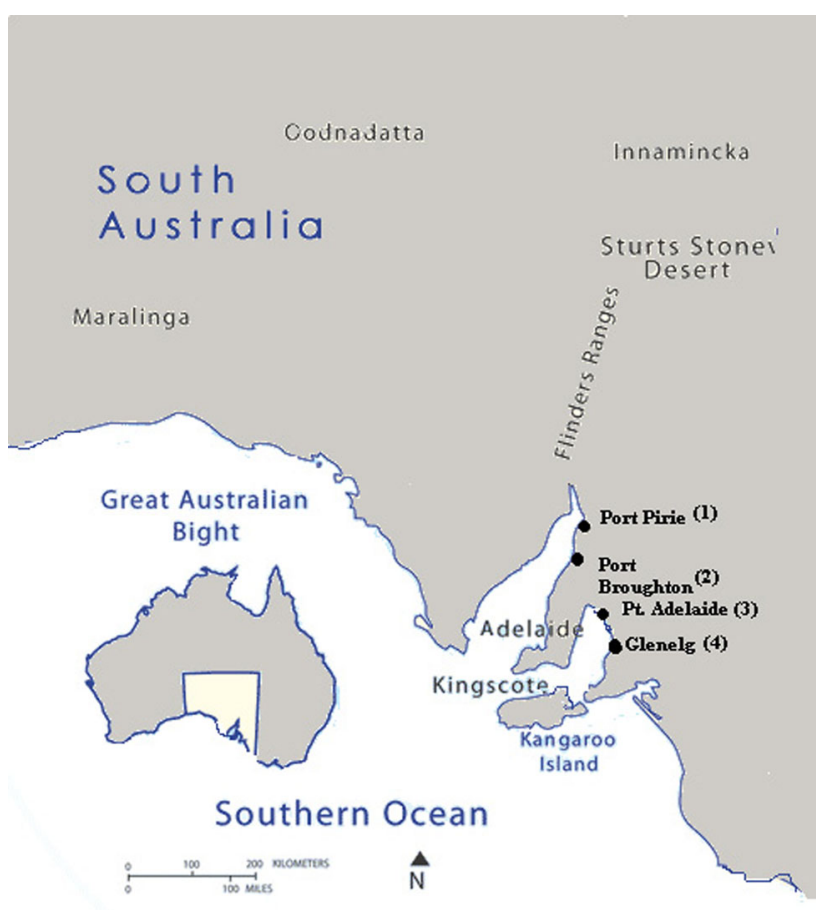

Fig. 1 Sampling locations along the South Australian coastline 
seawater, sediments and commonly occurring benthic macroalgae (seaweeds) belonging to Chlorophyceae (green), Phaeophyceae (brown) and Rhodophyceae (red) were sampled. At Site 1, Port Pirie $\left(33^{\circ} 10^{\prime} 839^{\prime \prime}\right.$ S; $138^{\circ}$ $01^{\prime} 147^{\prime \prime}$ E) the largest lead smelter in the world has been releasing large quantities of heavy metal effluents into the South Australian marine and aerial environments since 1889 (Ward and Hutchings 1996). Three distinct locations were chosen in Port Pirie from around the smelter to obtain a representative picture of the level of contamination. At Site 2, Port Broughton ( $\left.33^{\circ} 35^{\prime} 969^{\prime \prime} \mathrm{S} ; 137^{\circ} 55^{\prime} 716^{\prime \prime} \mathrm{E}\right)$ receives agricultural run-off via the Broughton River and is an area where the seagrass community has been significantly degraded due to the hot El Nino summer (Seddon et al. 2000). At Site 3, Port Adelaide ( $34^{\circ} 50^{\prime} 46^{\prime \prime} \mathrm{S} ; 138^{\circ}$ $30^{\prime} 11^{\prime \prime} \mathrm{E}$ ), is bounded by the Port River and Inner Harbour to the north and west and by Webb Street and Grand Junction Road to the south harbouring the Adelaide Brighton cement factory along with a massive sewage works pumping an average of 37 million litres of effluent directly into the river. At Site 4, Glenelg North Beach $\left(34^{\circ} 59^{\prime} 00^{\prime \prime} \mathrm{S} ; 138^{\circ} 31^{\prime} 00^{\prime \prime} \mathrm{E}\right)$ is south of the Holdfast Bay boat ramp and breakwaters. The surrounding land is heavily urbanized, and this beach directly receives discharges from the Barcoo outlet, which is the principle discharge point for local stormwater run-off to the sea. It is also close to the Glenelg wastewater treatment plant (WWTP) and the Patawalonga Basin.

Seawater and sediment sampling and laboratory preparation

Seawater was collected in polyethylene bottles in the field, filtered through disposable $0.45 \mu \mathrm{m}$ cellulose acetate filters (Millipore, USA) and preserved using $5 \%$ (v/v) nitric acid prior to transfer to the laboratory. All seawater samples were stored at $4{ }^{\circ} \mathrm{C}$ prior to metal analysis. Intertidal surface (top $5 \mathrm{~cm}$ ) sediments were also collected from all four sites. At each site, three discrete samples were taken within an area of approximately $10 \mathrm{~m}^{2}$, removed with a polyethylene scoop and immediately wet-sieved with local marine water to separate the fine-grained sand $(<250 \mu \mathrm{m})$ and the coarse-grained sand $(>250 \mu \mathrm{m}$ and $<2 \mathrm{~mm})$. Sediment fractions were transferred to polyethylene bottles and transported to the laboratory under cool conditions. Sediments were subsequently dried to constant mass at $60{ }^{\circ} \mathrm{C}$ prior to further treatment.

Seaweed sampling and preparation

Algae were handpicked from substratum (mud and concrete surfaces) of the intertidal zone and placed into foodgrade plastic bags for transfer to the laboratory in insulated (cool) containers. Specimens were chosen because of their different morphological and physiological characteristics and also for their widespread occurrence in South Australian coastal waters. Immediately after reaching the laboratory (within $4 \mathrm{~h}$ ), the samples $(0.5-1 \mathrm{~kg}$ ) were washed twice with local seawater from the sampling site followed by single distilled water to remove any adhering impurities, sand debris or epiphytes and freeze-dried at $-20{ }^{\circ} \mathrm{C}$ for $48 \mathrm{~h}$ prior to further treatment. After freeze drying, algal samples were crushed and homogenized in a porcelain mortar and stored at $4{ }^{\circ} \mathrm{C}$ until analysed. Algal species were identified by staff from the State Herbarium of South Australia, and voucher specimens prepared and deposited in their permanent collection.

\section{Seaweed extraction}

Freeze-dried and ground algal material $(0.500 \mathrm{~g})$ was weighed directly into a $75-\mathrm{mL}$ glass digestion tube and cold-digested in a fume cupboard overnight $(16 \mathrm{~h})$ with concentrated nitric acid $(5 \mathrm{~mL})$. The next morning, the sample was heated using a commercially available AIM 500 automated temperature controlled block digestion system (A.I. Scientific Pty. Ltd., Australia). Digestion blocks were programmed to slowly ramp to $140{ }^{\circ} \mathrm{C}$ over $8 \mathrm{~h}$ and then to maintain temperature. Sample digestion was continued at $140{ }^{\circ} \mathrm{C}$ until only a small residual liquid remained in each tube $(\approx 1 \mathrm{~mL})$. The tubes were subsequently removed from the digest block and allowed to cool to room temperature in the fume cupboard prior to dilution with $0.1 \%(\mathrm{v} / \mathrm{v}) \mathrm{HNO}_{3}(20 \mathrm{~mL})$. The samples were mixed thoroughly by vortexing and filtered through Whatman No. 42 filter papers directly into plastic containers for storage prior to analysis. Each batch of digests included blanks, duplicates, spikes and certified reference materials at a rate of $5 \%$. Spiked samples were prepared by addition of a $10 \mathrm{ppm}$ multi-mix standard $(200 \mu \mathrm{L})$ of selected heavy metals prior to digestion to give a concentration of $100 \mathrm{ppb}$ in the final digestion $(200 \mu \mathrm{L}$ of $10 \mathrm{ppm}$ standard in $20 \mathrm{~mL}$ ). The certified reference material was Bush Branches and leaves (GBW07603), National Research Centre for Certified Reference Materials, China. In general, the high observed recoveries ( $>96 \%$ ) of heavy metals with low RSD $(<12 \%)$ indicated that the digest was accurate and precise.

\section{Sediment extraction}

Dried and powdered sediment $(0.25 \mathrm{~g})$ was weighed directly into a Teflon microwave digestion vessel and colddigested for $10 \mathrm{~min}$ with freshly prepared aqua regia $(10 \mathrm{~mL})$ added using a disposable syringe. The microwave vessel was subsequently sealed and then digested using a 
MARS-X microwave accelerate reaction system (CEM Corporation, USA), using the recommenced USEPA method $3051 \mathrm{H}$ aqua regia dissolution procedure (USEPA 1998). Digested samples were cooled for at least $15 \mathrm{~min}$ in the fumehood, and the digest transferred to a volumetric flask and diluted up to $50 \mathrm{~mL}$ with $0.1 \%$ (v/v) $\mathrm{HNO}_{3}$ and allowed to stand overnight. Diluted samples were filtered through $0.45 \mu \mathrm{m}$ cellulose acetate disposable filters using disposable syringes into ICP sampler tubes for metal analysis. The certified reference material was soil GBW07411 (Chinese Soil) from the National Research Centre for Certified Reference Materials, China. In general, the accuracy of the digest method was confirmed with high recoveries $(>96 \%)$ of heavy metals from the standard reference material with low RSD $(<3 \%)$.

Instrumental analysis

Total metal concentrations were determined simultaneously using an Agilent 7500c inductively coupled plasma mass spectrometer (ICP-MS) equipped with an ASX-510 autosampler (CETAC, USA). The 7500c used an octopole reaction system in conjunction with a multi-tune facility including $\mathrm{He}$ and $\mathrm{H}_{2}$ as make up gases in addition to the standard (no gas) mode to minimize isotopic interferences which are important in highly saline soils such as seawater. ${ }^{102} \mathrm{Ru}$ was used as an internal standard. Blanks, standards and spiked samples were all used for analytical quality control at a rate of $>5 \%$. Continuous check of variation $(\mathrm{CCV})$ samples included in an instrumental run at a concentration of $50 \mathrm{ppb}$ in an aqueous $2 \%(\mathrm{v} / \mathrm{v}) \mathrm{HNO}_{3}$ solution had an average metal recovery of $101 \pm 2 \%$, and high purity water blanks were low indicating that ICP-MS response was satisfactory. Duplicate analysis of selected samples of both plants and soils $(n=4)$ had RSD $<5 \%$ indicating that precision was also satisfactory. However, the average spiked recovery of $200 \mu \mathrm{g} \mathrm{L}^{-1}$ for selected heavy metals in seawater was $112 \%$ indicating a slight overestimation of metal content in seawater samples presumably due to the complex seawater matrix, despite the use of the reaction cell technology to suppress polyatomic interferences.

\section{Statistical analysis}

All statistical procedures used the Analysis ToolPak available with Microsoft Excel (Microsoft 1997). Analysis of variance (ANOVA) was used to assess relationships between heavy metal concentration and potential environmental factors (sampling location, metal element and algal species). The student $t$ test was used to evaluate significance of differences in sediment concentrations between two particle sizes $(\leq 250$ and $>250 \mu \mathrm{m})$. Concentration factors in each alga were calculated for individual metals as the ratio of metal in the alga to that in the corresponding seawater from the same location.

\section{Results and discussion}

\section{Metal concentrations in seawater}

The concentrations of ten heavy metals commonly detected in the seawater at all four sampling locations, including the three distinct sites from Port Pirie are summarized in Table 1. Two-way ANOVA indicated that while overall there was no significant variation in the heavy metal concentrations of the seawater from the six sampling sites at the 0.05 significance level $\left(F_{5,9}=1.92\right.$; $\left.F_{\text {crit }}=2.42 ; P<0.05\right)$, there were significant differences between metals $\left(F_{5,9}=39.1 ; F_{\text {criti }}=2.1 ; P<0.05\right)$. Oneway ANOVA within individual elements did, however, indicate significant spatial variations in individual elemental concentrations with the four sampling locations at the 0.05 significance level (Table 1). Port Pirie had the highest overall average total metal seawater concentration

Table 1 Heavy metal concentrations $\left(\mu \mathrm{g} \mathrm{L}^{-1}\right)$ in seawater at each sampling location compared to the relevant Australian guideline values for marine waters

\begin{tabular}{lllllllllll}
\hline Sampling location & As & Cd & Co & Cr & $\mathrm{Cu}$ & $\mathrm{Fe}$ & $\mathrm{Mn}$ & $\mathrm{Ni}$ & $\mathrm{Pb}$ & $\mathrm{Zn}$ \\
\hline Port Pirie site 1 (PP001) & $8.2 \mathrm{a}$ & $0.77 \mathrm{a}$ & $4.3 \mathrm{~b}$ & $0.47 \mathrm{~b}$ & $2.7 \mathrm{c}$ & $218 \mathrm{a}$ & $157 \mathrm{a}$ & $1.8 \mathrm{a}$ & $55 \mathrm{a}$ & $67 \mathrm{a}$ \\
Port Pirie site 2 (PP002) & $8.0 \mathrm{ab}$ & $0.80 \mathrm{a}$ & $4.6 \mathrm{ab}$ & $0.35 \mathrm{~b}$ & $2.7 \mathrm{c}$ & $228 \mathrm{a}$ & $70 \mathrm{a}$ & $1.7 \mathrm{a}$ & $55 \mathrm{a}$ & $59 \mathrm{a}$ \\
Port Pirie site 3 (PP003) & $6.1 \mathrm{~b}$ & $0.43 \mathrm{~b}$ & $4.2 \mathrm{~b}$ & $0.35 \mathrm{~b}$ & $1.7 \mathrm{c}$ & $192 \mathrm{a}$ & $42 \mathrm{~b}$ & $1.7 \mathrm{a}$ & $16 \mathrm{~b}$ & $36 \mathrm{a}$ \\
Port Broughton (PB001) & $7.7 \mathrm{ab}$ & $0.13 \mathrm{~d}$ & $5.0 \mathrm{a}$ & $0.55 \mathrm{~b}$ & $1.8 \mathrm{c}$ & $176 \mathrm{a}$ & $6.5 \mathrm{c}$ & $1.9 \mathrm{a}$ & $0.4 \mathrm{c}$ & $14 \mathrm{~b}$ \\
Glenelg Beach (GB001) & $5.7 \mathrm{~b}$ & $0.13 \mathrm{~d}$ & $4.3 \mathrm{~b}$ & $0.35 \mathrm{~b}$ & $0.9 \mathrm{~b}$ & $250 \mathrm{a}$ & $9.1 \mathrm{c}$ & $1.4 \mathrm{~b}$ & $3.0 \mathrm{bc}$ & $17 \mathrm{~b}$ \\
Port Adelaide (PA001) & $3.2 \mathrm{c}$ & $0.24 \mathrm{c}$ & $2.2 \mathrm{c}$ & $1.32 \mathrm{a}$ & $64.2 \mathrm{a}$ & $348 \mathrm{a}$ & $33 \mathrm{~b}$ & $0.3 \mathrm{c}$ & $10.7 \mathrm{bc}$ & $33 \mathrm{a}$ \\
Marine Guideline $^{\mathrm{a}}$ & 24 & 5.5 & 1 & 4.4 & 1.3 & - & - & 70 & 4.4 & 15
\end{tabular}

Within individual elements, concentrations annotated with the same letters do not vary significantly from each other at the 0.05 significance level

a Australian water quality guideline values suitable for the protection of $95 \%$ of all species (ANZECC/ARMCANZ 2000) 
and with a few exceptions the highest individual seawater metal concentrations. Since the high seawater metal concentrations observed at Port Adelaide for $\mathrm{Fe}$ and at Port Broughton for $\mathrm{Co}$ and $\mathrm{Ni}$ were not statistically significantly higher than those observed at Port Pirie, the only statistically significant higher individual metal concentrations were observed for $\mathrm{Cr}$ and $\mathrm{Cu}$ at Port Adelaide (Table 1). These observations were principally attributed to effluents discharged from the smelter in the vicinity of Port Pirie and the presence of industrial and commercial complexes in Port Adelaide. In comparison, Port Broughton and Glenelg which lack any industrial activities were less contaminated. These observations corroborated previous studies that had indicated that metals were not uniformly distributed along the coast, but were concentrated in two hotspots: Port Pirie, in the upper Spencer Gulf, and Adelaide, Gulf of Saint Vincent (Edwards et al. 2001). Earlier reports had also shown that the concentrations of all metals at Port Pirie were elevated, with $\mathrm{Pb}$ and Zn being of particular concern (Ferguson 1983; Richardson et al. 1994).

In general, the three Port Pirie sites had similar metal levels which were all elevated relative to the other three sites. The highest concentrations of $\mathrm{Cd}\left(0.8 \mu \mathrm{g} \mathrm{L}^{-1}\right), \mathrm{Pb}$ $\left(55 \mu \mathrm{g} \mathrm{L}^{-1}\right)$ and $\mathrm{Zn}\left(67 \mu \mathrm{g} \mathrm{L}^{-1}\right)$ were all observed at Port Pirie, and these higher concentrations, compared to the other three geographic locations, were most likely due solely to the presence of the $\mathrm{Pb}$ and $\mathrm{Zn}$ smelter at Port Pirie. In a previous study, samples taken directly from the effluent channel from the Port Pirie smelter had significantly elevated levels of $\mathrm{Cd}\left(64 \mu \mathrm{g} \mathrm{L}^{-1}\right), \mathrm{Pb}\left(750 \mu \mathrm{g} \mathrm{L}^{-1}\right)$ and $\mathrm{Zn}\left(4,300 \mu \mathrm{g} \mathrm{L}^{-1}\right)$, and the further samples were taken from the smelter dilution with seawater reduced the levels to those of the near-surface seawater (Ferguson 1983). Thus, while not as high as effluent channel concentrations, the levels of $\mathrm{Cd}, \mathrm{Pb}$ and $\mathrm{Zn}$ determined here were all still slightly higher than the average background levels of $\mathrm{Cd}$ $\left(0.3 \mu \mathrm{g} \mathrm{L}^{-1}\right), \mathrm{Pb}\left(0.4 \mu \mathrm{g} \mathrm{L}^{-1}\right)$ and $\mathrm{Zn}\left(<10 \mu \mathrm{g} \mathrm{L}^{-1}\right)$ for the Spencer Gulf (Ferguson 1983). The small differences in the concentrations observed between the two studies were attributed to normal variations in spatial and temporal sampling.

Iron concentrations across all locations ranged from 176 to $348 \mu \mathrm{g} \mathrm{L}^{-1}$ with the highest level detected at Port Adelaide and the lowest at Port Broughton, although statistically there was no significant difference in $\mathrm{Fe}$ level with site (Table 1). While elevated Fe concentrations in seawaters occur due to weathering of naturally occurring iron minerals such as goethite, hematite, magnetite and siderite, the presence of elevated concentrations of heavy metals in seawater cannot readily be attributed to mineral weathering and is more likely an indicator of anthropogenic contamination (Carral et al. 1995; Williams 1996).
Of the other metals determined, As and Mn were also found to be highest at Port Pirie. After Port Pirie, the next most contaminated location was Port Adelaide, which had the highest concentrations of $\mathrm{Cr}\left(1.32 \mu \mathrm{g} \mathrm{L}^{-1}\right)$ and $\mathrm{Cu}$ $\left(64.2 \mu \mathrm{g} \mathrm{L}^{-1}\right)$ where the differences in elemental distributions suggested a different type of contaminant source than that observed at Port Pirie. The other two sampling locations, Port Broughton and Glenelg Beach, were less contaminated as indicated by the consistently lower metal concentrations in seawater (Table 1). Other metals $(\mathrm{Co}, \mathrm{Cr}$ $\mathrm{Fe}$ and $\mathrm{Ni}$ ), with the exception of Port Adelaide where the lowest levels of both $\mathrm{Co}$ and $\mathrm{Ni}$ were observed, did not vary significantly with site. Previous analysis of seawater from the shallow tidal Barker Inlet (Harbinson 1986), near Port Adelaide, reported average concentrations for $\mathrm{Cu}, \mathrm{Fe}$, $\mathrm{Mn}$ and $\mathrm{Zn}$ of 5.7, 87, 219 and $21.5 \mu \mathrm{g} \mathrm{L}^{-1}$, respectively, which were of the same magnitude as the values determined here (Table 1).

Overall, while there was considerable variation in metal concentrations with site, in general, Glenelg and Port Broughton were less contaminated. While no exceedance of available Australian water, quality guidelines (ANZECC/ARMCANZ 2000) were observed for As, $\mathrm{Cd}, \mathrm{Cr}$ or $\mathrm{Ni}$ at any site, concentrations generally significantly exceeded guideline values for $\mathrm{Cu}, \mathrm{Pb}$ and $\mathrm{Zn}$ at Port Pirie and Port Adelaide, while Co was consistently high across all sites (Table 1). The major differences in the distribution of metals in seawater from the six sampling locations were attributed to increased discharges of industrial wastes at Port Pirie from the smelter and at Port Adelaide from the surrounding industries, commercial establishments and recreational activities. Previous studies on the distributions of heavy metal concentrations in Adelaide metropolitan water samples support this assertion (Harbinson 1986; Fernandes et al. 2008; Lavery et al. 2008).

\section{Metal concentrations in sediments}

While seawater concentrations tend to be transient and are subject to tidal flows and other movements that quickly disperse metal concentrations unless the effluent source is ongoing, analysis of sediments is often more indicative of long-term contaminant exposure, as metals generally accumulate in sediments over time, and the concentrations are not as susceptible to short-term temporal fluctuations. The sediment metal concentrations observed in this study were magnified a number of times for most of the metals compared to seawater concentrations indicating sediments to be a sink for heavy metal contamination, and as was observed for seawater, heavy metal concentrations were highest in Port Pirie sediments, followed by Port Adelaide sediments, suggesting that the deposition rate of the metals was relative to the metal concentrations in seawater. 
Elevated concentrations in sediments result from either low remobilization rates into water or the dominance of metal removal pathways from the water column such as precipitation (Rainbow 1995). Variations in the metal content of sediments are generally a result of metal deposition and particle sedimentation rates, particle size and organic content (Phillips and Rainbow 1994). It is well documented that the bulk of the total metals measured in sediment tends to be associated with the finer particles, which have a greater surface area (Hong 1993). This was also observed in this study where irrespective of sampling location, sediment samples of $<250 \mu \mathrm{m}$ contained the highest total metal concentrations. Concentrations of the metals in the Port Pirie sediments decreased in the order $\mathrm{Fe}>\mathrm{Zn}>\mathrm{Pb}>\mathrm{Mn}>\mathrm{Co}>\mathrm{Cu}>\mathrm{Cd}>\mathrm{As}>\mathrm{Cr}>\mathrm{Ni}$ (Table 2). Generally, coastal sediments and water show higher concentrations of $\mathrm{Fe}$ and $\mathrm{Mn}$ (Sanchez-Rodriguez et al. 2001). In addition, elevated levels of $\mathrm{Pb}$ and $\mathrm{Zn}$ might be due to the close proximity of the smelter. However, at Port Pirie site 2 (PP002), the Cd concentration was inexplicably very high compared to all other samples (Table 2). While some Cd elevation might be generally expected at Port Pirie from smelter activities and the common association of $\mathrm{Cd}, \mathrm{Pb}$ and $\mathrm{Zn}$ mineral phases, this should have also been observed at the other two Port Pirie sites (PP001 and PP002). The only difference was that PP002 was situated near mangrove vegetation, which generally increases the organic content of the sediment. Since organic matter is a significant factor in influencing metal distribution due to binding of heavy metals (Balkis and Çagatay 2001), the elevated levels of $\mathrm{Cd}$ may be attributed to increased organic matter content of the sediment at PP002. This seems likely as $\mathrm{Cu}$, which also readily forms strong complexes with organic matter, is also elevated at PP002 relative to the other two sites (Table 2). The highest concentration of $\mathrm{Pb}\left(2,425 \mu \mathrm{g} \mathrm{g}^{-1}\right)$ was detected at PP002 for the $<250 \mu \mathrm{m}$ fraction, while the lowest $\mathrm{Pb}$ concentration $\left(2.5 \mu \mathrm{g} \mathrm{g}^{-1}\right)$ was found in the Glenelg sediment sample $>250 \mu \mathrm{m}$. Similarly, the highest concentration of $\mathrm{Zn}\left(7,974 \mu \mathrm{g} \mathrm{g}^{-1}\right)$ was also found at PP002 in the $<250 \mu \mathrm{m}$ sediment fraction. As and $\mathrm{Cu}$ were also found at relatively higher concentrations in Port Pirie samples compared to all other locations. While the maximum As $\left(59.6 \mu \mathrm{g} \mathrm{g}^{-1}\right)$ and $\mathrm{Cd}$ concentrations $\left(125 \mu \mathrm{g} \mathrm{g}^{-1}\right)$ were found in PP002 $<250 \mu \mathrm{m}$, a minimum of $0.03 \mu \mathrm{g} \mathrm{g}^{-1}$ was recorded in Glenelg sediments of $<250 \mu \mathrm{m}$. Interestingly, $\mathrm{Co}$ and $\mathrm{Cr}$ were found to be highest, 112 and $69 \mu \mathrm{g} \mathrm{g}^{-1}$, respectively, in the PA001 $(<250 \mu \mathrm{m})$ sample, potentially indicating a very different industrial pollution source than that of Port Pirie. Student $t$ tests to determine whether there was a significant difference in the metal concentrations of the sediments between the two size fractions, indicated that in general, there was no statistical difference between

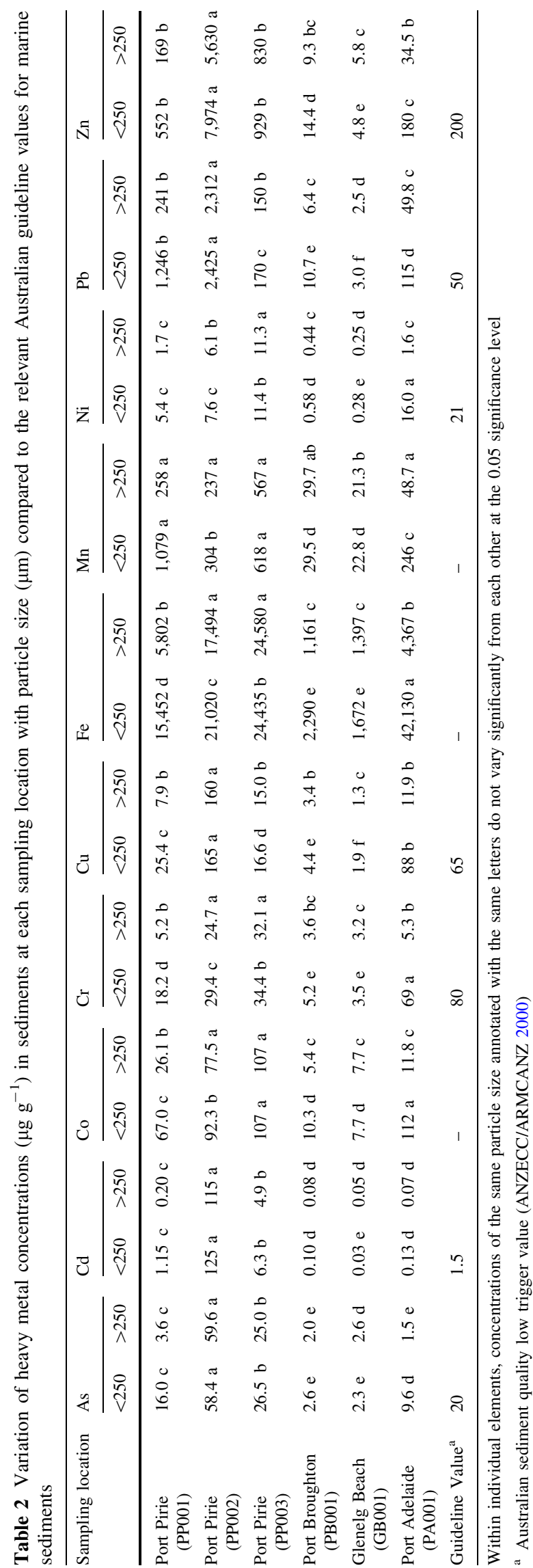


metal concentrations of the two sediment particle sizes at the 0.05 level of significance (Table S1; Supplementary Information). However, for a large range of metals, metal concentrations in sediments from PP001 to PB001 of different particle size were significantly different (Table S1; Supplementary Information).

As was observed with metal concentration in seawaters, one-way ANOVA within individual elements of the same particle size indicated significant spatial variations in individual elemental concentrations with sampling locations at the 0.05 significance level (Table 2) with exceedance of sediment quality guidelines at some locations. At Port Pirie and to a lesser extent at Port Adelaide, relative to the low trigger values (ANZECC/ARMCANZ 2000), elevated levels of $\mathrm{As}, \mathrm{Cd}, \mathrm{Pb}$ and $\mathrm{Zn}$ were observed (Table 2), while at Port Broughton and Glenelg sediments did not exceed any trigger values and could therefore be classified as relatively uncontaminated. Copper was generally low across most sites and only exceeded low trigger values at PP002 and PA001, while $\mathrm{Cr}$ and Ni did not exceed low sediment trigger values at any site. Thus, overall, irrespective of particle size, sediments from Port Pirie were generally more contaminated than the other three sites with overall contamination decreasing in the order PP002 $>$ PP003 $>$ PP001. Port Adelaide was the next most contaminated site, followed by Port Broughton and Glenelg having the least contaminated sediments. The elevated concentrations determined here for Port Pirie support earlier studies where sediments in the upper Spencer Gulf near the smelter of Port Pirie were found to contain up to $7,700 \mu \mathrm{g} \mathrm{g}^{-1} \mathrm{~Pb}, 17,000 \mu \mathrm{g} \mathrm{g}^{-1} \mathrm{Zn}$, $460 \mu \mathrm{g} \mathrm{g}^{-1} \mathrm{Cd}, 160 \mu \mathrm{g} \mathrm{g}^{-1} \mathrm{As}$ (Tiller et al. 1989), while leaves of seagrass from the area contained up to $402 \mu \mathrm{g} \mathrm{g}^{-1} \mathrm{~Pb}$ and $1,050 \mu \mathrm{g} \mathrm{g}^{-1} \mathrm{Zn}$, suggesting that at least some portion of the sediment metal concentration was bioavailable (Tiller et al. 1989).

Metal concentrations in algae

Although the concentrations of $\mathrm{Cd}, \mathrm{Cu}, \mathrm{Pb}$ and $\mathrm{Zn}$ determined here were similar to those determined in four species of macroalgae sampled from the Gulf of St Vincent from 1981 to 1983 (Maher 1986), the concentration of all heavy metals in algae showed significant variation with species and sampling location (Table 3). Spatial variations in the metal contents of seaweeds and variations in metal accumulation in laboratory studies are believed to be related to changes in growth and metabolic rates, which are influenced by local and seasonal environmental conditions, interactions among metal ions resulting in competition for binding sites in seaweed, life span of the species, growth rates and morphology (Villares et al. 2002; Ryan et al. 2012). Although the accumulation of non-essential elements ( $\mathrm{As}, \mathrm{Cr}, \mathrm{Cd}$ and $\mathrm{Pb}$ ) was considered independent of physiological requirements (Higgins and Mackey 1987), earlier reports had shown that brown seaweeds were capable of accumulating As a hundred times more than terrestrial plants (Keiji and Kanji 1989). Although it was not possible to individualize a contaminant gradient among the seaweed taxa, both species which accumulated the maximum amount of As were brown algae, and the next highest As concentration of $67 \mu \mathrm{g} \mathrm{g}^{-1}$ was accumulated by the green algae Blidingia marginata and all other species accumulated less than half of these amounts (Table 3). For As, both the highest and the lowest algal concentrations were found in samples from Glenelg. A maximum As concentration of $79 \mu \mathrm{g} \mathrm{g}^{-1}$ was detected in two algal species (Cystophora monillifera and Sargassum cinctum), while Ulva lactuca accumulated the lowest concentration of As $\left(3.3 \mu \mathrm{g} \mathrm{g}^{-1}\right)$, suggesting different accumulation capacities and specificity of metal uptake by the different benthic macroalgal forms when exposed to the same degree of pollutant. It is now well recognized that different classes of algae accumulate different amounts of metals, particularly As, with the order of accumulation generally following the sequence brown $>$ red $>$ green (Díaz et al. 2012; Ryan et al. 2012). Such inter-species patterns in As accumulation have also previously been reported in Australian marine macroalgae (Maher and Clarke 1984, Tukai et al. 2002). Thus, we attribute the higher accumulation of As by $C$. monillifera and S. cinctum, to being brown algae and the lower As accumulation of U. lactuca to being a green alga. Tukai et al. (2002) suggested that this may be directly related to uptake of macroalgal phosphate, since As accumulation was greater when phosphorus was also accumulated and brown macroalgae accumulated more phosphorous than either red or green macroalgae.

Algae sampled from the three sites of Port Pirie exhibited several times higher concentrations of $\mathrm{Pb}$ and $\mathrm{Zn}$ compared to the other three sites. The Port Pirie site also had the maximum concentration of $\mathrm{Pb}$ and $\mathrm{Zn}$ in both seawater and sediments. Accumulation of $\mathrm{Pb}$ in algae was highest in B. marginata $\left(974 \mu \mathrm{g} \mathrm{g}^{-1}\right)$ from Port Pirie and lowest in S. cinctum from Glenelg Beach $\left(0.92 \mu \mathrm{g} \mathrm{g}^{-1}\right) . \mathrm{Pb}$ concentrations of up to $3,213 \mu \mathrm{g} \mathrm{g}^{-1}$ for Ulva.,with mean values of 748 to $206 \mu \mathrm{g} \mathrm{g}^{-1}$ had been previously reported (Malea and Haritonidis 2000). All other algal species except Anotrichium tenue $\left(34.6 \mu \mathrm{g} \mathrm{g}^{-1}\right)$ and $U$. lactuca $\left(17.9 \mu \mathrm{g} \mathrm{g}^{-1}\right)$ showed negligible concentrations of $\mathrm{Pb}$. Similarly, Zn was highest in the algal tissue collected from Port Pirie. Zinc concentrations in algae decreased in the order B. marginata $\left(3,162 \mu \mathrm{g} \mathrm{g}^{-1}\right)>$ Hormophysa cuneiformis (393 and $162.8 \mu \mathrm{g} \mathrm{g}^{-1}$ in PP001 and PP002). However, A. tenue also accumulated $224 \mu \mathrm{g} \mathrm{g}^{-1}$ of $\mathrm{Zn}$ though it was collected from Port Adelaide. Algae generally accumulate $\mathrm{Zn}$ from seawater (Ho 1988), although Zn 
Table 3 Heavy metal concentration $\left(\mu \mathrm{g} \mathrm{g}^{-1}\right)$ in algae at each sampling location

\begin{tabular}{|c|c|c|c|c|c|c|c|c|c|c|c|}
\hline Sampling location & Algal species & As & $\mathrm{Cd}$ & Co & $\mathrm{Cr}$ & $\mathrm{Cu}$ & $\mathrm{Fe}$ & $\mathrm{Mn}$ & $\mathrm{Ni}$ & $\mathrm{Pb}$ & $\mathrm{Zn}$ \\
\hline Port Pirie site 1 (PP001) & H. cuneiformis & 15.0 & 3.5 & 3.1 & 2.5 & 37.3 & 314 & 773 & 1.1 & 838 & 163 \\
\hline Port Pirie site 2 (PP002) & H. cuneiformis & 19.9 & 6.6 & 3.0 & 4.3 & 11.5 & 265 & 87.8 & 0.6 & 202 & 393 \\
\hline Port Pirie site 3 (PP003) & Blidingia marginata & 66.8 & 65.6 & 43.3 & 17.5 & 63.9 & 8,712 & 278 & 8.1 & 974 & 3,162 \\
\hline \multirow[t]{2}{*}{ Port Broughton (PB001) } & Scaberia agardhii & 23.3 & 0.21 & 1.8 & 2.3 & 3.3 & 175 & 32.7 & 0.3 & 3.5 & 15.9 \\
\hline & C. cephalornithos & 22.3 & 0.08 & 1.5 & 1.5 & 2.6 & 162 & 41.8 & 0.3 & 2.5 & 15.5 \\
\hline \multirow[t]{9}{*}{ Glenelg Beach (GB001) } & Acrosorium polyneurum & 20.0 & 0.06 & 7.6 & 1.2 & 6.4 & 1,174 & 5.4 & 2.0 & 2.0 & 51.2 \\
\hline & Cystophora monillifera & 79.4 & 0.04 & 1.4 & 0.8 & 4.8 & 209 & 5.66 & 0.2 & 1.5 & 17.5 \\
\hline & Cystophora monilliformis & 6.0 & 0.10 & 8.9 & 3.7 & 13.9 & 1,750 & 36 & 0.6 & 3.2 & 42.1 \\
\hline & Dictyopteris australis & 13.4 & 0.05 & 13.7 & 5.2 & 50.3 & 2,698 & 22.5 & 0.9 & 6.1 & 63.0 \\
\hline & Gelidium micropterum & 18.3 & 0.04 & 17.3 & 5.0 & 10.2 & 3,635 & 29.0 & 1.4 & 5.4 & 48.4 \\
\hline & Gracilaria & 10.3 & 0.04 & 5.8 & 2.0 & 7.7 & 1,121 & 80.3 & 0.7 & 2.3 & 24.5 \\
\hline & Scaberia agardhii & 9.1 & 0.02 & 3.2 & 0.9 & 3.1 & 564 & 2.5 & 0.5 & 0.9 & 22.0 \\
\hline & Sargassum cinctum & 78.8 & 0.07 & 2.1 & 0.9 & 8.3 & 224 & 14.8 & 0.4 & 0.9 & 23.2 \\
\hline & Ulva lactuca & 3.3 & 0.06 & 2.0 & 0.9 & 46.7 & 268 & 6.0 & 0.3 & 3.6 & 41.6 \\
\hline \multirow[t]{2}{*}{ Port Adelaide (PA001) } & Anotrichium tenиe & 9.6 & 0.38 & 11.0 & 9.7 & 91.2 & 2,756 & 397 & 2.5 & 34.6 & 224 \\
\hline & Ulva lactuca & 6.8 & 0.11 & 5.0 & 2.1 & 45.5 & 540 & 309 & 2.2 & 17.9 & 112 \\
\hline
\end{tabular}

concentrations not exceeding $100 \mathrm{\mu g} \mathrm{g}^{-1}$ are suggested acceptable background levels for non-polluted areas (Moore and Ramamoorthy 1987). In this study, some Zn concentrations were 79 times this value indicative of significant $\mathrm{Zn}$ contamination in Port Pirie sediments.

Cadmium accumulated in negligible amounts in almost all of the algae except $B$. marginata, which accumulated the maximum $\mathrm{Cd}$ concentration of $66 \mu \mathrm{g} \mathrm{g}^{-1}$. In comparison, Hormophysa $c$. accumulated only 6.6 and $3.5 \mu \mathrm{g} \mathrm{g}^{-1}$, and the rest of the algae had $\mathrm{Cd}$ concentrations $<0.5 \mu \mathrm{g} \mathrm{g}^{-1}$. Moore and Ramamoorthy (1984) reported concentration ranges for $\mathrm{Cd}$ in three brown seaweeds sampled in a non-polluted area of the United Kingdom, from 0.15 to $0.43 \mu \mathrm{g} \mathrm{g}^{-1}$ dry weight. However, in contrast to previous studies where high concentrations of $\mathrm{Cd}$ were observed in Ulva (Malea and Haritonidis 2000; Leal et al. 1997), relatively lower concentrations of Cd were observed here for Ulva., which may be due to lower nitrate concentrations, limiting growth and resulting in a significant decrease in $\mathrm{Cd}$ accumulation by this species.

Accumulation of $\mathrm{Co}, \mathrm{Cr}$ and $\mathrm{Cu}$ was highest in $B$. marginata with concentrations of 43.3, 17.5 and $63.9 \mu \mathrm{g} \mathrm{g}^{-1}$, respectively, which was generally much higher than the accumulation observed in all other species collected. Accumulation of Co was maximum in B. marginata followed by Gelidium micropterum which were 40 and 20 times higher than previous studies of Gelidium microdon $\left(0.79 \mu \mathrm{g} \mathrm{g}^{-1}\right.$ at Ferraria) (Wallenstein et al. 2009). Accumulation of $\mathrm{Cu}$ was also relatively high in Dictyopteris australis $\left(50.3 \mu \mathrm{g} \mathrm{g}^{-1}\right)$ and $U$. lactuca from Glenelg (46.7 $\mu \mathrm{g} \mathrm{g}^{-1}$ ), while $U$. lactuca from Glenelg accumulated only $2.0 \mu \mathrm{g} \mathrm{g}^{-1}$ of $\mathrm{Co}$, which was the lowest
Co accumulation of all the species. While several species (B. marginata, D. australis, U. lactuca) accumulated considerable amounts of $\mathrm{Cu}$, Accumulation was highest in the red algae Anotrichium tenue. High concentrations of $\mathrm{Cu}$ in a variety of algae (Enterromorpha compressa, Chaetomorpha antennina, Centroceras clavulatum) from the Tamil Nadu coast of India had also previously been reported (Rajendran et al. 1993) as well as in one species, Monostroma hariotii, from Casey station, Antarctica (McMinn et al. 2004). This level of accumulation reflects the structural and functional importance of $\mathrm{Cu}$ as a major cell constituent in important physiological processes. The algal concentrations of $\mathrm{Cr}$ ranged between 0.76 and $17.5 \mu \mathrm{g} \mathrm{g}^{-1}$ and with the exception of Blidingia marginata all the other species studied contained $\mathrm{Cr}$ at levels similar to those previously reported (Villares et al. 2002).

Although high Fe concentrations were found in all species, the same pattern of accumulation with species was generally observed for Fe as had been observed for all the other metals. Thus, the maximum accumulation of $\mathrm{Fe}$ was observed in Blidingia marginata $\left(8,700 \mu \mathrm{g} \mathrm{g}^{-1}\right)$ followed by Caulocystis cephalornithos $\left(162 \mu \mathrm{g} \mathrm{g}^{-1}\right)$ which were comparable with seaweeds from the Venice lagoon (Caliceti et al. 2002) and Sao Miguel (Azores) in the North Atlantic Ocean (Wallenstein et al. 2009). The consistently high Fe concentrations encountered in seaweed are probably due to several factors including (1) the established need of Fe for normal growth of marine plants (Goldberg 1952), (2) the ability of most algal species to bioconcentrate Fe from the surrounding environment and (3) contamination from industrial and other operations (Eisler 1981). 
Table 4 Concentration factors for various metals and algae species sampled at six distinct sampling locations

\begin{tabular}{|c|c|c|c|c|c|c|c|c|c|c|c|}
\hline \multirow[t]{2}{*}{ Sampling location } & \multirow[t]{2}{*}{ Algae species } & \multicolumn{10}{|c|}{ Concentration factors } \\
\hline & & As & $\mathrm{Cd}$ & Co & $\mathrm{Cr}$ & $\mathrm{Cu}$ & $\mathrm{Fe}$ & $\mathrm{Mn}$ & $\mathrm{Ni}$ & $\mathrm{Pb}$ & $\mathrm{Zn}$ \\
\hline Port Pirie (PP001) & H. cuneiformis & 1.8 & 4.6 & 0.7 & 5.3 & 14.1 & 1.4 & 4.9 & 0.6 & 15.2 & 2.4 \\
\hline Port Pirie (PP002) & H. cuneiformis & 2.5 & 8.2 & 0.7 & 12.4 & 4.2 & 1.2 & 1.3 & 0.4 & 3.7 & 6.7 \\
\hline Port Pirie (PP003) & Blidingia marginata & 11.0 & 153 & 10.3 & 50.1 & 37.6 & 45.4 & 6.6 & 4.7 & 60.4 & 88.1 \\
\hline \multirow[t]{2}{*}{ Port Broughton (PB001) } & C. cephalornithos & 3.0 & 0.6 & 0.3 & 2.7 & 1.4 & 0.9 & 6.4 & 0.1 & 5.6 & 1.1 \\
\hline & Scaberia agardhii & 3.0 & 1.6 & 0.4 & 4.2 & 1.8 & 1.0 & 5.0 & 0.1 & 7.8 & 1.1 \\
\hline \multirow[t]{9}{*}{ Glenelg Beach (GB001) } & Acrosorium polyneurum Okamura & 3.5 & 0.5 & 1.8 & 3.3 & 7.2 & 4.7 & 0.6 & 1.4 & 0.7 & 3.0 \\
\hline & Cystophora monillifera & 14.0 & 0.3 & 0.3 & 2.2 & 5.4 & 0.8 & 0.6 & 0.2 & 0.5 & 1.0 \\
\hline & Cystophora monilliformis & 1.0 & 0.8 & 2.1 & 10.6 & 15.6 & 7.0 & 4.0 & 0.5 & 1.1 & 2.5 \\
\hline & Dictyopteris australis (Sonder) Askenasy & 2.4 & 0.4 & 3.2 & 14.9 & 56.5 & 10.8 & 2.5 & 0.6 & 2.0 & 3.7 \\
\hline & Gelidium micropterum & 3.3 & 0.3 & 4.1 & 14.1 & 11.4 & 14.6 & 3.2 & 1.0 & 1.8 & 2.8 \\
\hline & Gracilaria & 1.8 & 0.3 & 1.4 & 5.7 & 8.7 & 4.5 & 8.8 & 0.5 & 0.8 & 1.4 \\
\hline & Scaberia agardhii & 1.6 & 0.2 & 0.8 & 2.6 & 3.5 & 2.3 & 0.3 & 0.4 & 0.3 & 1.3 \\
\hline & Sargassum cinctum J. Agardh & 14.0 & 0.5 & 0.5 & 2.4 & 9.4 & 0.9 & 1.6 & 0.3 & 0.3 & 1.4 \\
\hline & Ulva lactuca & 0.6 & 0.5 & 0.5 & 2.7 & 52.5 & 1.1 & 0.7 & 0.2 & 1.2 & 2.4 \\
\hline \multirow[t]{2}{*}{ Port Adelaide (PA001) } & Anotrichium tenue (C. Agardh) Nägeli & 3.0 & 1.6 & 5.1 & 7.4 & 1.4 & 8.0 & 12.1 & 9.1 & 3.2 & 6.8 \\
\hline & Ulva lactuca & 2.1 & 0.5 & 2.3 & 1.6 & 0.7 & 1.6 & 9.4 & 7.9 & 1.7 & 3.4 \\
\hline
\end{tabular}

Accumulation of Mn was considerable in both species collected from Port Adelaide, where Anotrichium tenue and Ulva lactuca accumulated 397 and $309 \mu \mathrm{g} \mathrm{g}^{-1}$, respectively. Although the highest $\mathrm{Mn}$ accumulation of $773 \mu \mathrm{g} \mathrm{g}^{-1}$ was seen in Hormophysa cueniformis from Port Pirie, all other algal species contained $<100 \mu \mathrm{g} \mathrm{g}^{-1}$ $\mathrm{Mn}$. Negligible amounts of $\mathrm{Ni}$ were found in all species except Blidingia marginata, which accumulated $8.1 \mathrm{~g} \mathrm{~g} \mathrm{~g}^{-1} \mathrm{Ni}$. In comparison, species from Port Adelaide, Anotrichium tenue and Ulva lactuca, contained only 2.5 and $2.2 \mu \mathrm{g} \mathrm{g}^{-1} \mathrm{Ni}$, respectively. The highest accumulation of $\mathrm{Mn}$ and $\mathrm{Ni}$ was by Hormophysa cueniformis and Blidingia marginata, respectively, with concentrations similar to previous results obtained in algae from the Aegean Sea, Greece (Sawidis et al. 2001).

\section{Concentration factors in algae}

To find any antagonistic or synergistic relationships between the different metals accumulated by all of the algal species metal correlation, analyses were performed (Table S2; Supplementary Information). The literature suggests that antagonism occurs when the combined physiological effect of two or more elements is less than the sum of their independent effects, and synergism occurs when the combined effects of these elements are greater (Kabata-Pendias and Pendias 1989). In our study, some metals exhibited synergistic accumulation by algae. Lead and zinc showed strong positive correlations $(r=0.973$ at 0.05 level of significance). Similarly, $\mathrm{Pb}$ and $\mathrm{Cd}$
( $r=0.986), \mathrm{Zn}$ and $\mathrm{Cd}(r=0.971), \mathrm{Cu}$ and $\mathrm{Cr}(r=0.98)$, $\mathrm{Zn}$ and $\mathrm{Mn}(r=0.91), \mathrm{Ni}$ and As $(r=0.926)$. This was may be due to the high bioavailability of the metals due to presence of common metal sources like smelters, metal processing industry effluents and sewage and agricultural run-off. A similar correlation was reported by Sfriso et al. (1995) and Moore and Ramamoorthy (1984). However, the antagonistic effect was also evident, as in some instances the accumulation of one metal did not favour the accumulation of another, as depicted by the strong significant negative correlation found between the metals. Cobalt showed significant negative correlation at 0.05 level with $\mathrm{Cu}(r=-0.954), \mathrm{Fe}(r=-0.929)$, and Ni $(r=-0.959)$. Nickel also showed significant negative correlation with $\mathrm{Cu} \quad(r=-0.950)$ and $\mathrm{Fe}(r=-0.959)$. Interactions observed within plants between trace metals have also indicated that these processes are quite complex, being at times both antagonistic and synergistic in nature, and occasionally are involved in the metabolism of more than two elements. The antagonistic metals are mostly linked to processes of absorption by plants and to the enzymatic pathway (Kitagishi and Obata 1981).

The concentrations of heavy metals in littoral seaweeds have previously been used as an indicator of regional differences in the dissolved trace metal content of estuarine and coastal waters. This is possible due to the ability of marine algae to concentrate metals and to integrate the exposed metal concentration in seawater over a reasonably long time interval and thus smooth out any large, but shortterm, fluctuations in these concentrations. Constancy of 
mean concentration factors has been reported earlier (Foster 1976). The concentration factor, calculated by dividing the mean metal concentration in the algae by the mean metal concentration in seawater, for the different algal species (Table 4) showed slightly different patterns from the normal accumulation pattern. Concentration factors $(\mathrm{CF})$ significantly varied with respect to metal, alga and site. Blidingia marginata showed the highest concentration factor for the majority of the metals $(\mathrm{Cd}, \mathrm{Co}, \mathrm{Cr}, \mathrm{Fe}$, $\mathrm{Pb}$ and $\mathrm{Zn}$ ), while $D$. australis showed the maximum $\mathrm{CF}$ for $\mathrm{Cu}$, Cystophora monillifera for As and Anotrichium tenue for $\mathrm{Mn}$ and $\mathrm{Ni}$.

Therefore, Blindigia marginata appears to be good biomonitor species as it accumulates heavy metals in its tissues in relatively significant quantities and may therefore be analysed as a measure of the bioavailability of a large number of metals in the ambient habitat. It also produces a simple correlation between metal concentration in tissues (body) and average ambient bioavailable metal concentration over a recent time period. The study also suggests that in biomonitoring programmes, site differences in metal concentrations can be inferred using data from individual species, but it is also necessary to make interspecies comparisons involving comparisons of families and orders of sites.

\section{Conclusion}

The overall level of heavy metal contamination in seawater and sediments decreased in the order of Port Pirie $>$ Port Adelaide $>$ Glenelg $\geq$ Port Broughton, where sediment metal concentrations generally increased with decreasing particle size. This preliminary investigation supports the notion that macroalgae can differentially accumulate metal contaminants from waters and sediments of the South Australian coastline. Although the concentration of trace elements in macroalgae samples ranged widely, reflecting both contaminations in the water column and in the sediment, the heavy metal concentrations found in the seaweed species studied were comparable to the levels previously reported in the literature for industrialized coastal areas. Of the thirteen algal species evaluated, the highest concentrations of trace metals were found in Blidingia marginata for $\mathrm{Cd}, \mathrm{Co}, \mathrm{Cr}, \mathrm{Cu}, \mathrm{Fe}, \mathrm{Pb}$ and $\mathrm{Zn}$; Cystophora monillifera for As and Anotrichium tenue for Mn and Ni. Due to its widespread distribution in South Australian coastal waters and its ease of recognition, Blidingia marginata is recommended as a biomonitor species for future studies.

Acknowledgments We thank Dr Gurgel and R.N. Baldock from the State Herbarium of South Australia for identification of the algae. Dr Gareth Lewis is also acknowledged for his considerable assistance and advice during field work. Dr Sukalyan Chakraborty acknowledges the financial support from the Australian government in providing an Endeavour research fellowship and Dr Gary Owens acknowledges the financial support of the University of South Australia under its divisional research 'seedling' funding for development of projects. The Centre for Environmental Risk Assessment and Remediation (CERAR), University of South Australia is acknowledged for providing laboratory facilities.

\section{References}

ANZECC/ARMCANZ (2000) Australian and New Zealand guidelines for fresh and marine waters. National Water Quality Management Strategy Paper No 4, Australian and New Zealand environment and conservation council/agriculture resource management council of Australia and New Zealand, Canberra

Balkis N, Çağatay MN (2001) Factors controlling metal distributions in the surface sediments of the Erdek Bay, Sea of Marmara Turkey. Environ Int 27(1):1-13

Batley GE (1995) Heavy metals and tributyltin in Australian coastal and estuarine waters. State of the marine environment report for Australia, technical annex 2, pollution. In: LP Zann, DC Sutton (eds) Department of the environment, sport and territories. pp 63-72

Bellgrove A, Clayton MN, Quinn GP (1997) Effects of secondarily treated sewage effluent on intertidal macroalgal recruitment processes. Mar Freshwater Res 48:137-146

Burridge TR, Bidwell J (2002) Review of the potential use of brown algal ecotoxicological assays in monitoring effluent discharge and pollution in Southern Australia. Mar Pollut Bull 45(1-12):140-147

Caliceti M, Argese E, Sfriso A, Pavoni B (2002) Heavy metal contamination in the seaweeds of the Venice Lagoon. Chemosphere 47:443-454

Carral E, Puente X, Villares R, Carballeira A (1995) Background heavy metal levels in estuarine sediments and organisms in Galicia (northwest Spain) as determined by modal analysis. Sci Total Environ 172:175-188

Chaudhuri A, Mitra M, Havrilla C, Waguespack Y, Schawrz J (2007) Heavy metal biomonitoring by seaweeds on the Delmarva Peninsula, East Coast of the USA. Bot Mar 50:151-158

Claisse D, Alzieu C (1993) Copper contamination as a result of antifouling paint regulations. Mar Pollut Bull 26(7):395-397

Connell SD, Russell BD, Turner DJ (2008) Recovering a lost baseline: missing kelp forests from a metropolitan coast. Mar Ecol-Prog Ser 360:63-72

Díaz O, Tapia Y, Muñoz O, Montoro R, Velez D, Almela C (2012) Total and inorganic arsenic concentrations in different species of economically important algae harvested from coastal zones of Chile. Food Chem Toxicol 50:744-749

Edwards JW, Edyvane KS, Boxal VA, Hamann M, Soole KL (2001) Metal levels in seston and marine fish flesh near industrial and metropolitan centers in South Australia. Mar Pollut Bull 42(5):389-396

Eisler RI (1981) Trace metal concentrations in marine organisms. Pergamon Press, Oxford

Ferguson J (1983) Concentration and speciation of lead, zinc and cadmium in seawater-like smelter effluent and adjacent marine environments, Port Pirie, South Australia. Aust J Mar Fresh Res 34:375-385

Fernandes C, Fontaínhas-Fernandes A, Cabral D, Salgado MA (2008) Heavy metals in water, sediment and tissues of Liza saliens from Esmoriz-Paramos lagoon, Portugal. Environ Monit Assess $136: 267-275$ 
Foster P (1976) Concentration and concentration-factors of heavy metals in brown algae. Environ Pollut 10:45-53

Goldberg ED (1952) Iron assimilation by marine diatoms. Biol Bull 102:243-248

Gosavi K, Sammut J, Gifford S, Jankowski J (2004) Macroalgal biomonitors of trace metal contamination in acid sulfate soil aquaculture ponds. Sci Total Environ 324:25-39

Harbinson P (1986) Diurnal variations in the chemical environment of a shallow Tidal inlet, Gulf St Vincent, South Australia: implications for water quality and trace metal mitigation. Mar Environ Res 20:161-195

He Z, Morrison RJ (2001) Changes in the marine environment of port Kembala Harbour, NSW, Australia, 1975-1995: a review. Mar Pollut Bull 42(3):193-201

Higgins HW, Mackey DJ (1987) Role of Ecklonia radiata (C.Ag.) J. Agardh in determining trace metal availability in coastal waters I. Total trace metals. Aust J Mar Fresh Res 38:307-315

Ho YB (1988) Metal levels in three intertidal macroalgae in Hongkong waters. Aquat Bot 29:367-372

Hong H (1993) Victoria Harbour contaminated sediment study report. Publication 93-03. Hong Kong: The Hong Kong University of Science and Technology Research Centre 89

Kabata-Pendias A, Pendias H (1989) Trace elements in soils and plants. Mir, Moscow, pp 152-186

Keiji I, Kanji H (1989) Seaweed: chemical composition and potential food uses. Food Rev Int 5(1):101-144

Kitagishi K, Obata H (1981) Accumulation of heavy metals in rice grains. In: Kitagishi K, Yamane I (eds) Heavy metal pollution in soils of Japan. Japan Sci Soc Press, Tokyo, pp 95-104

Lavery TJ, Butterfield N, Kemper CM, Reid RJ, Sanderson K (2008) Metals and selenium in the liver and bone of three dolphin species from South Australia, 1988-2004. Sci Total Environ 390:77-85

Leal FMC, Vasconcelos MT, Sousa-Pinto I, Cabral JPS (1997) Biomonitoring with benthic macroalgae and direct assay of heavy metals in seawater of the Oporto coast (Northwest Portugal). Mar Pollut Bull 34(12):1006-1015

Maher WA (1986) Trace metal concentrations in marine organisms from St. Vincent Gulf, South Australia. Water Air Soil Poll 29(1):77-84

Maher WA, Clarke SM (1984) The occurrence of arsenic in selected marine macroalgae from two coastal areas of South Australia. Mar Pollut Bull 15(3):111-112

Malea P, Haritonidis S (2000) Use of the green alga Ulva rigida C. Agardh as an indicator species to reassess metal pollution in the Thermaikos Gulf, Greece, after 13 years. J Appl Phycol 12:169-176

McMinn A, Runcie JW, Riddle M (2004) Effect of seasonal sea ice breakout on the photosynthesis of benthic diatom mats at Casey, Antarctica. J Phycol 40:62-69

Melville F, Pulkownik A (2006) Investigation of mangrove macroalgae as bio indicators of estuarine contamination. Mar Pollut Res 52(10):1260-1269

Microsoft ${ }^{\circledR}$ Excel 97 (1997) Analysis tool pak, Microsoft Corporation Millward GE, Turner A (2001) Metal pollution. In: Steele JH, Thorpe SA, Turekian SA (eds) Encyclopaedia of ocean sciences. Academic, San Diego, pp 1730-1737

Misheer N, Kindness A, Jonnalagadda SB (2006) Elemental uptake by seaweed, Plocamium corallorhiza along the Kwazulu-natal coast of Indian Ocean, South Africa. J Environ Sci Heal B 41(6): 1037-1048

Moore JW, Ramamoorthy S (1984) Heavy metals in natural waters, applied monitoring and impact assessment. Springer, New York, p 268

Moore JW, Ramamoorthy S (1987) Heavy metals in natural waters: applied monitoring and impact assessment. Mir, Moscow, p 286
Olivier F, Ridd M, Klumpp D (2002) The use of transplanted cultured tropical oysters (Saccostrea commercialis) to monitor Cd levels in North Queensland coastal waters (Australia). Mar Pollut Bull 44:1051-1062

Phillips DJH, Rainbow PS (1994) Biomonitoring of trace aquatic contaminants, 2nd edn. Chapman and Hall, London, p 371

Rainbow PS (1995) Biomonitoring of heavy metal availability in the marine environment. Mar Pollut Bull 31(4-12):183-192

Rainbow PS (2006) Biomonitoring of trace metals in estuarine and marine environments. Aust J Ecotoxcol 12:107-122

Rajendran K, Sampathkumar P, Govindasamy C, Ganesan M, Kannan R, Kannan L (1993) Levels of trace metals (Mn, Fe, Cu and Zn) in some Indian seaweeds. Mar Pollut Bull 26(5):283-285

Richardson BJ, Garnham JS, Fabris JG (1994) Trace metal concentrations in mussels (Mytilus edulis planulatus L.) transplanted into southern Australian waters. Mar Pollut Bull 28(6):392-396

Ryan S, McLoughlin P, O'Donovan O (2012) A comprehensive study of metal distribution in three main classes of seaweed. Environ Pollut 167:171-177

Sanchez-Rodriguez I, Huerta-Diaz MA, Choumiline E, HolguinQuinones O, Zertuche-Gonzalez JA (2001) Elemental concentrations in different species of seaweeds from Loreto Bay, Baja California Sur, Mexico: implications for the geochemical control of metals in algal tissue. Environ Pollut 114(2):145-160

Sawidis T, Brown MT, Zachariadis G, Sratis I (2001) Trace metal concentrations in marine macroalgae from different biotopes in the Aegean Sea. Environ Int 27:43-47

Seddon S, Connolly RM, Edyvane KS (2000) Large-scale seagrass dieback in northern Spencer Gulf, South Australia. Aquat Bot 66:297-310

Sfriso A, Marcomini A, Zanette M (1995) Heavy metals in sediments, SPM and phytozoobenthos of the lagoon of Venice. Mar Pollut Bull 30(2):116-124

Tanabe S (1994) International mussel watch in Asia-Pacific. Mar Pollut Bull 28(9):518

Tiller KG, Merry RH, Zarcinas BA, Ward TJ (1989) Regional geochemistry of metal-contaminated surficial sediments and seagrasses in upper Spencer gulf South Australia. Estuar Coast Shelf Sci 28(5):473-493

Tukai R, Maher WA, McNaught IJ, Ellwood MJ, Coleman M (2002) Occurrence and chemical form of arsenic in marine macroalgae from the east coast of Australia. Mar Freshwater Res 53:971-980

US Environmental Protection Agency (1998) Method 3015A, microwave assisted acid digestion of aqueous samples and extracts, In: USEPA methods. EPA, Washington, pp 3015A/1-3015A/18

Villares R, Puente X, Carballeira A (2002) Seasonal and background levels of heavy metals in two green seaweeds. Environ Pollut 119:79-90

Wallenstein FM, Couto RP, Amaral AS, Wilkinson M, Neto AI, Rodrigues AS (2009) Baseline metal concentrations in marine algae from São Miguel (Azores) under different ecological conditions - urban proximity and shallow water hydrothermal activity. Mar Pollut Bull 58(3):439-444

Ward TJ, Hutchings PA (1996) Effects of trace metals on infaunal species composition in polluted intertidal and subtidal marine sediments near a lead smelter, Spencer Gulf, South Australia. Mar Ecol-Prog Ser 135:123-135

Wilkinson J, Hutson J, Bestland E, Fallowfield H (2005a) Audit of contemporary and historical quality and quantity data of stormwater discharging into the marine environment, and field work programme. ACWS Technical Report No. 3 prepared for the Adelaide Coastal Waters Study Steering Committee, July 2005. Department of Environmental Health, Flinders University of South Australia 
Wilkinson J, White N, Smythe L, Fallowfield H, Hutson J, Bestland E, Simmons C, Lamontagne S (2005b) Volumes of inputs, their concentrations and loads received by adelaide metropolitan coastal waters. ACWS technical report No. 12 prepared for the Adelaide Coastal Waters Study Steering Committee, September 2005. Flinders centre for coastal and catchment environments, Flinders University of SA
Williams C (1996) Combatting marine pollution from land-based activities: australian initiatives. Ocean Coast Manage 33(1-3): 87-112

Zann LP (1995) The state of the marine environment report for Australia. Technical summary. Department of the Environment, Sport and Territories, Canberra, Australia 